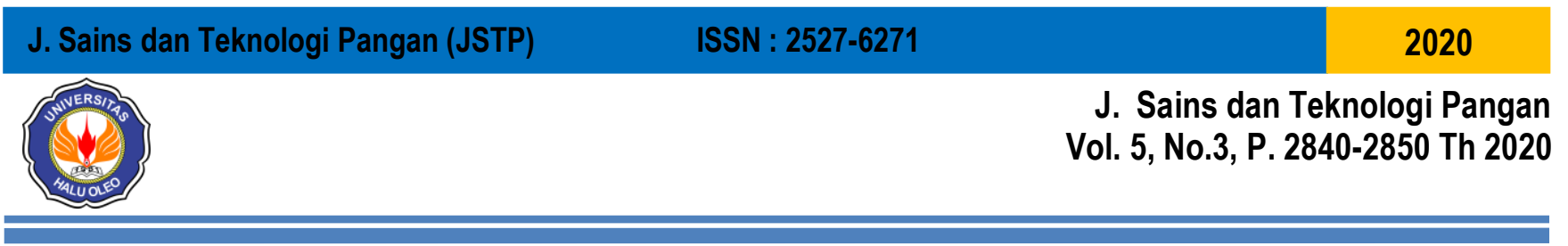

\title{
PENGARUH SUBSTITUSI YOGHURT DAN TEPUNG KACANG HIJAU (Phaseolus radiatus) TERHADAP PENILAIAN ORGANOLEPTIK, KANDUNGAN PROTEIN DAN KALSIUM PUDING SILKY SEBAGAI MAKANAN TAMBAHAN ALTERNATIF UNTUK ANAK STUNTING
}

[The Effect of Yoghurt and Green Bean Flour Substitution (Phaseolus radiatus) on Organoleptic Assessment,
Protein Content and Calcium Content in Silky Pudding as Alternative Food Supplement for Stunting Children]

\author{
Evi Kusumawati ${ }^{1 *}$, Suriana Koro ${ }^{1}$, Tantri Bana ${ }^{1}$ \\ 1 Jurusan Gizi, Politeknik Kesehatan Kendari \\ *Email : (evikusumawati214@gmail.com, (Telp: +6281227002879)
}

Diterima tanggal 17 Februari 2020

Disetujui tanggal 15 Juni 2020

\begin{abstract}
The purpose of this study was to determine protein and calcium contents as well as the organoleptic assessment of silky pudding with yogurt and Mung bean (Phaseolus radiatus) flour substitution. In this study, the pudding formulation was modified by adding yogurt and green bean flour in different concentrations consisting of four treatments namely P0 (Yogurt: Mung bean flour = 100:0), P1 (Yogurt: Mung bean flour = 50:50), P2 (Yogurt:Mung bean flour = 25:75) and P3 (Yoghlurt: Mung bean flour $=0: 100)$. Next, the organoleptic test and analysis of protein and calcium contents in the product were performed. This was a pre-experimental study with a randomized block design (RBD). Data were analyzed using the Kruskal Wallis Test and continued with the Post Hoc Test at a 95\% confidence level. Organoleptic test results show that the P2 product was the most preferred by panelists after P0 (control). P2 silky pudding was preferred by panelists and fulfilled the quality requirements of the SNI 01-2802-2015 since it had bright greenish color, sweet taste, soft and supple texture, as well as fragrant aroma (according to the constituent ingredients). The chemical analysis results of the $P 2$ silky pudding product show that it contained $0.67 \mathrm{~g}$ protein and $130 \mathrm{mg}$ calcium. The protein and calcium contents of $P 2$ silky pudding were higher than the standard pudding. The P2 silky pudding product could contribute $2.58 \%$ to the protein and $20 \%$ to the calcium requirements of children aged less than five years old.
\end{abstract}

Keywords: Silky pudding, yogurt, green beans, stunting

ABSTRAK

Tujuan penelitian untuk mengetahui penilaian organoleptik, kandungan protein dan kalsium dari puding silky yang disubstitusi yoghurt dan tepung kacang hijau (Phaseolus radiatus). Penelitian ini memodifikasi formulasi puding dengan penambahan yoghurt dan tepung kacang hijau dengan konsentrasi berbeda yang terdiri dari empat perlakuan yaitu P0 (Yoghurt: Tepung kacang hijau $=100: 0$ ), P1 (Yoghurt: Tepung kacang hijau $=50: 50$ ), P2 (Yoghurt: Tepung kacang hijau $=25: 75$ ) dan P3 (Yoghurt : Tepung kacang hijau $=0: 100$ ). Selanjutnya dilakukan uji organoleptik dan analisa kandungan protein dan kalsium pada produk. Jenis penelitian yang digunakan adalah penelitian pre experimental dengan rancangan acak kelompok (RAK). Data dianalisis dengan menggunakan Uji Kruskal Wallis dan dilanjutkan dengan Uji Pos Hoc pada taraf kepercayaan 95\%. Hasil uji organoleptik menunjukkan bahwa produk P2 adalah produk yang paling disukai oleh panelis setelah P0 (kontrol). Puding silky P2 dapat diterima dari segi organoleptik karena disukai panelis serta telah memenuhi syarat mutu puding SNI 01-2802-2015 yaitu pada parameter warna cerah agak kehijauan, rasa manis, tekstur lembut dan kenyal, aroma harum (sesuai bahan penyusun). Hasil analisis kimia produk puding silky P2 mengandung protein $0,67 \mathrm{~g}$ dan calsium $130 \mathrm{mg}$, kandungan protein dan calsium puding silky P2 lebih tinggi bila dibandingkan dengan puding standar. Produk puding silky P2 berkontribusi sebesar 2,58\% terhadap kecukupan gizi protein dan 20\% terhadap kecukupan gizi kalsium anak balita,

Kata kunci: Puding Silky, yoghurt, kacang hijau, stunting 


\section{PENDAHULUAN}

Stunting merupakan kondisi kurang energi protein kronis, data Riskesdas 2018 menyebutkan bahwa angka prevalensi stunting di Sulawesi Tenggara masih tinggi yakni sebesar $29,9 \%$, hal ini berbanding terbalik dengan target RPJMN yang seharusnya prevalensi stunting tinggal $28 \%$. Sehingga perlu dilakukan pengkajian kembali agar dapat menurunkan prevalensi stunting di Sulawesi Tenggara (Kemenkes, 2018).

Asupan protein, kalsium, dan fosfor signifikan lebih rendah pada anak stunting dibandingkan pada anak tidak stunting usia 24-59 bulan di Kota Pontianak (Sari, 2016). Pemberian makanan tambahan sangat penting untuk meningkatkan asupan energi dan protein. Produk silky pudding bisa dimanfaatkan sebagai alternative makanan tambahan untuk anak stunting karena merupakan salah satu dessert favorit banyak orang, utamanya pada anak-anak. Untuk meningkatkan kandungan protein dan kalsium pada silky pudding maka perlu dilakukan substitusi pada bahan dasar yaitu dengan penambahan yoghurt dan kacang hijau.

Yoghurt merupakan salah satu hasil olahan susu yang di fermentasi yang banyak mengandung zat gizi. Proses fermentasi yang terjadi pada yoghurt akan menambah kandungan pada gizinya. Komposisi zat gizi yoghurt mirip dengan susu. Bahkan, ada beberapa komponen yang jumlahnya lebih tinggi dibanding dengan susu, seperti vitamin B kompleks, kalsium (Ca), dan protein. Selama proses fermentasi susu menjadi yoghurt terjadi sintesis vitamin B kompleks khususnya thiamin (vitamin B2), serta beberapa asam amino penyusun protein (Yasjudani, 2017).

Menurut hasil penelitian yang di lakukan oleh Yasjudani tahun 2017 mengenai daya terima silky pudding dengan penambahan yoghurt dan buah naga, panelis rata - rata menyukai silky pudding yang telah dimodifikasi tersebut. Namun yang paling disukai ialah Formula yang ke tiga dengan presentase bahan $100 \%$ yaitu yoghurt sebanyak 200 gram dan buah naga juga sebanyak 200 gram.

Kacang hijau (Phaseolus radiatus) merupakan tanaman yang dapat tumbuh hampir di semua tempat di Indonesia Kacang hijau memiliki kandungan protein yang cukup tinggi sebesar $22 \%$ dan merupakan sumber mineral penting, antara lain kalsium dan fosfor yang bermanfaat untuk memperkuat tulang (Nurhalimah (2012)). Asupan protein menyediakan asam amino yang diperlukan tubuh untuk membangun matriks tulang dan aksi osteotropic hormone IGF-I (Level plasma insulin growth factor) yang memiliki konsekuensi jangka panjang terhadap pertumbuhan (Sari, 2016).

Oleh karenanya peneliti tertarik untuk memodifikasi kembali formulasi-formulasi bahan yang telah di buat oleh peneliti sebelumnya dengan menggunakan kacang hijau dan yoghurt sebagai bahan tambahan dengan konsentrasi yang berbeda - beda. Adapun tujuan dari penelitian ini adalah untuk mengetahui tingkat perbedaan daya terima puding silky dari semua aspek penilaian (warna, aroma, rasa, tekstur) dengan penambahan yoghurt 
dan kacang hijau dengan konsentrasi berbeda, serta untuk mengetahui kandungan kalsium dan protein berdasarkan perlakuan terbaik.

\section{BAHAN DAN METODE}

\section{Bahan}

Bahan yang digunakan adalah kacang hijau, yoghurt biokul plain, susu cair UHT ultramilk, agar-agar, gula dan garam.

\section{Proses Pembuatan Tepung Kacang Hijau (Haryono dan Larasati, 2017)}

Biji kacang hijau dibersihkan kemudian ditiriskan, kecambah biji kacang hijau dikeringkan dengan menggunakan sinar matahari, disangrai selama \pm 15 menit, apabila telah kering, kemudian di haluskan menggunakan alat blender dan setelah itu diayak menggunakan ayakan 80 mesh, tepung kacang hijau halus disimpan pada wadah tertutup.

\section{Proses Pembuatan Puding Silky (Yasjudani, 2017)}

a. Tahap Persiapan

Menyiapkan semua alat, bahan utama dan bahan tambahan yang diperlukan dalam pembuatan puding, kemudian menimbang bahan bahan yang diperlukan sesuai dengan berat bahan pada resep.

b. Tahap Pelaksanaan

Tahap pelaksanaan pembuatan puding meliputi tahap pencampuran, pemasakkan dan pendinginan, pencampuran susu cair full cream, bubuk jellly, gula pasir serta garam pada panci stainless dan diaduk hingga merata, setelah itu tambahkan yoghurt dan tepung kacang hijau dari 4 perbandingan dengan berat bahan yang berbeda-beda, pemasakan, setelah semua bahan tercampur dan teraduk rata, kemudian dimasak pada api sedang sambil terus diaduk agar larut merata hingga mendidih, setelah mendidih, dituang pada cup puding, pendinginan, setelah semua wadah terisi lalu diletakkan dalam lemari pendigin

\section{Uji Organoleptik}

Uji organoleptik adalah penilaian yang menggunakan indera manusia. Jenis uji organoleptik yang digunakan adalah uji kesukaan/hedonik menyatakan suka/tidaknya terhadap suatu produk. Uji hedonik adalah pengujian yang dilakukan untuk mengetahui tingkat daya terima konsumen dengan mempergunakan skala hedonik, yaitu sangat suka (skor 4), suka (skor 3), kurang suka (skor 2) dan tidak suka (skor 1). Jumlah panelis 45 orang dengan kriteria panelis tidak terlatih. 


\section{Uji Kimia Puding Silky Substitusi Yoghurt dan Tepung Kacang Hijau}

Analisis kimia puding silky substitusi yoghurt dan tepung kacang hijau meliputi pengukuran kadar protein dan kadar calcium, karena tujuan substitusi yohgurt dan tepung kacang hijau pada puding silky adalah untuk meningkatkan kadar protein dan kalsium puding silky sehingga diharapkan dapat menjadi alternatif makanan tambahan pada anak stunting. Kadar protein diukur menggunakan metode Kjedahll dan kadar kalsium menggunakan metode Atomic Absorbtion Spectrophotometry (AAS), dimana pengukuran kadar protein dan kadar kalsium pada pudding silky substitusi yoghurt dan tepung kacang hijau dilakukan pengulangan sebanyak tiga kali untuk melihat keakuratan hasil pengukuran

\section{Rancangan Penelitian}

Penelitian ini menggunakan Rancangan Acak Kelompok (RAK), untuk mengetahui adanya perbedaan pada variabel warna, aroma, rasa maupun tekstur baik pada kelompok control (P0 = yoghurt $200 \mathrm{~g}$ ) maupun kelompok perlakuan (P1 = Yoghurt $100 \mathrm{~g}+$ Tepung kacang hijau $100 \mathrm{~g}),(\mathrm{P} 2=$ Yoghurt $50 \mathrm{~g}+$ Tepung kacang hijau $150 \mathrm{~g}$ ) dan P3 (Tepung kacang hijau $200 \mathrm{~g}$ ). Untuk masing-masing perlakuan dibuat 2 kali ulangan sampel dan 2 ulangan analisa. Panelis dalam penelitian ini adalah mahasiswa tingkat I Prodi DIV Jurusan Gizi Poltekkes Kemenkes Kendari yang berjumlah 45 mahasiswa, data uji organoleptik diperoleh menggunakan formulir penilaian uji hedonik dengan skala penilaian 1-4, atribut yang dinilai meliputi warna, aroma, rasa dan tekstur. Data kadar protein dan calsium diukur dengan uji prosimat, yaitu metode Kjedahll untuk protein dan metode AAS untuk kalsium.

\section{Analisis Data}

Analisa daya terima menggunakan pendekatan secara kuantitatif dan deskriptif, kemudian dianalisis dengan menggunakan komputer melalui program SPSS (Statistic Program For Social Science) for Windows 16.0. Uji statistik untuk mengetahui perbedaan antara perlakuan dari atribut warna, aroma, rasa dan tekstur dilakukan uji Kruskal Wallis dengan taraf signifikan 0,05. Selanjutnya untuk mengetahui perbedaan dari keempat perlakuan dilakukan uji Post Hoc dengan taraf signifikan 0,05.

\section{HASIL DAN PEMBAHASAN}

Penilaian organoleptik meliputi penilaian kesukaan panelis terhadap warna, aroma, rasa dan tekstur produk puding silky yang disubstitusi yoghurt dan Tepung Kacang Hijau (Phaseolus radiatus) dengan tujuan 


\section{J. Sains dan Teknologi Pangan}

Vol. 5, No.3, P. 2840-2850 Th 2020

untuk menentukan produk puding silky yang paling disukai oleh panelis. Hasil produk puding silky dapat dilihat pada Gambar 1.

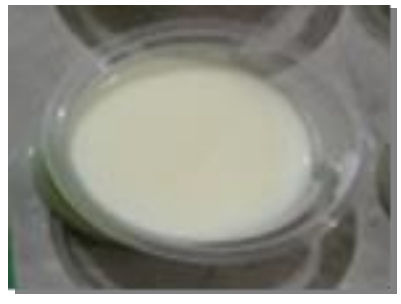

$\mathrm{PO}$

(Yoghurt : Tepung kacang hijau $=100: 0)$

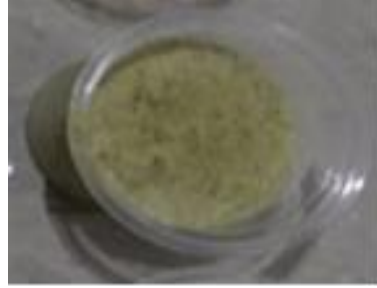

PI

(Yoghurt : Tepung kacang hijau $=50: 50$ )

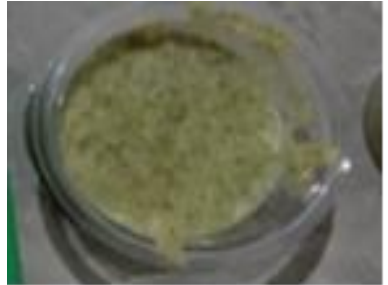

P2

(Yoghurt : Tepung kacang hijau $=25: 75$ )

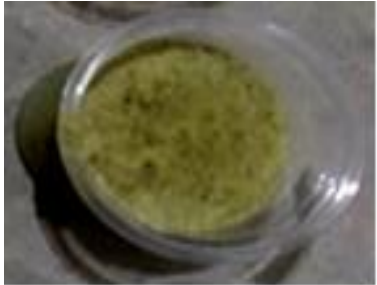

P3

(Yoghurt : Tepung kacang hijau $=0: 100$ )

Gambar 1. Hasil produk puding silky dengan berbagai formulasi

\section{Penilaian Organoleptik terhadap Warna Puding Silky}

Warna merupakan parameter awal yang secara subjektif dan visual harus dipertimbangkan karena dapat menyebabkan penerimaan atau penolakan produk. Penentuan mutu suatu bahan pangan pada umumnya tergantung pada warna, karena warna tampil terlebih dahulu (Winarno, 2004).

Pada Tabel 1, menunjukkan bahwa penilaian tertinggi panelis terhadap karakteristik organoleptik warna silky pudding adalah pada produk P0 karena berwarna putih cerah. Produk P2 adalah puding silky yang warnanya paling disukai oleh panelis setelah produk P0. Puding silky P2 memiliki warna cerah agak kehijauan. Puding silky P1 berwarna kurang maksimal yaitu hijau pudar karena perbandingan tepung kacang hijau yang sedikit sehingga membuat tingkat kesukaan panelis terhadap warna menjadi berkurang, sedangkan puding silky P3 berwarna hijau kecokelatan, karena besarnya perbandingan tepung kacang hijau, pengaruh pemanasan dan perebusan. Hasil uji statistik menunjukkan bahwa ada perbedaan atribut warna pada setiap produk $(p=0,000)$

Tabel 1. Rerata dan Standar Deviasi Penilaian Organoleptik Warna Produk Puding Silky

\begin{tabular}{ccc}
\hline Produk Puding Silky & Rerata & $p$ \\
\hline P0 (Yoghurt : Tepung kacang hijau $=100: 0)$ & $3,11 \pm 0,68$ & \\
PI (Yoghurt : Tepung kacang hijau $=50: 50)$ & $2,33 \pm 0,79$ & 0,000 \\
P2 (Yoghurt : Tepung kacang hijau $=25: 75)$ & $2,57 \pm 0,75$ & \\
P3 (Yoghurt : Tepung kacang hijau $=0: 100)$ & $2,40 \pm 0,0,8$ & \\
\hline
\end{tabular}
Keterangan : Uji Kruskal-Wallis

Kacang hijau berwarna hijau karena mengandung klorofil, pengaruh perebusan dan pemanasan akan menyebabkan warna hijau pada kacang hijau menjadi agak kecoklatan, klorofil yang berwarna hijau berubah menjadi hijau kecoklatan akibat substitusi magnesium dan hidrogen membentuk feofitin (klorofil yang kehilangan magnesium) (Winarno, 2004). 


\section{Penilaian Organoleptik terhadap Aroma Puding Silky}

Aroma adalah bau yang ditimbulkan oleh rangsangan kimia yang tercium oleh syaraf-syaraf olfaktori yang berada dalam rongga hidung (Winarno, 2004). Pada Tabel 2, menunjukkan bahwa penilaian tertinggi panelis terhadap karakteristik organoleptik aroma puding silky adalah pada produk P0 karena bebas aroma langu. Produk P1 adalah puding silky yang aromanya paling disukai oleh panelis setelah produk P0. Puding silky P1 memiliki aroma harum seperti susu, aroma langu pada tepung kacang hijau masih tertutupi oleh aroma susu. Puding silky P2 beraroma harum kacang hijau, aroma langu pada pada tepung kacang hijau masih tertutupi oleh aroma susu walaupun prosentase penambahan tepung kacang hijau semakin tinggi yaitu 75\%, tingkat kesukaan panelis pada puding silky P2 agak berkurang mungkin karena puding silky P2 tidak beraroma seperti puding pada umumnya, sedangkan puding silky P3 beraroma agak langu karena prosentase penambahan tepung kacang hijau $100 \%$. Walaupun demikian hasil uji statistik menunjukkan bahwa tidak ada perbedaan atribut aroma pada setiap produk $(p=0,096)$

Tabel 2. Rerata dan Standar Deviasi Penilaian Organoleptik Aroma Produk Puding Silky

\begin{tabular}{ccc}
\hline Produk Puding Silky & Rerata & $p$ \\
\hline P0 (Yoghurt : Tepung kacang hijau $=100: 0)$ & $3,57 \pm 0,81$ & \\
PI (Yoghurt : Tepung kacang hijau $=50: 50)$ & $2,53 \pm 0,72$ & 0,096 \\
P2 (Yoghurt : Tepung kacang hijau $=25: 75)$ & $2,37 \pm 0,80$ & \\
P3 (Yoghurt : Tepung kacang hijau $=0: 100)$ & $2,15 \pm 1,08$ & \\
\hline
\end{tabular}
Keterangan : Uji Kruskal-Wallis

Aroma kacang hijau yang langu tidak disukai oleh panelis, aroma langu akan berkurang saat diberi perlakuan panas. Bau langu disebabkan oleh aktivitas enzim lipoksigenase yang secara alami ada pada kacangkacangan. Enzim lipoksigenase akan menyerang rantai asam lemak tidak jenuh dan menghasilkan senyawa yang lebih kecil bobot molekulnya, terutama senyawa aldehid dan keton (Astawan, 2009). Enzim lipoksigenase mengkatalis reaksi pemecahan lemak tidak jenuh,kemudian akan memicu pembentukan senyawa volatil yang menyebabkan bau langu (Andarwulan dan Kusnandar, 2011)

\section{Penilaian Organoleptik terhadap Rasa Puding Silky}

Rasa merupakan komponen utama dalam menentukan tingkat penerimaan suatu produk, karena rasa dapat membuat produk menjadi lebih bernilai dan disukai oleh konsumen (Effendi, 2009) 
Tabel 3. Rerata dan Standar Deviasi Penilaian Organoleptik Rasa Produk Puding Silky

\begin{tabular}{ccc}
\hline Produk Puding Silky & Rerata & $p$ \\
\hline P0 (Yoghurt : Tepung kacang hijau $=100: 0)$ & $2,22 \pm 0,97$ & \\
PI (Yoghurt : Tepung kacang hijau $=50: 50)$ & $1,91 \pm 0,89$ & 0,038 \\
P2 (Yoghurt : Tepung kacang hijau $=25: 75)$ & $2,42 \pm 0,75$ & \\
P3 (Yoghurt : Tepung kacang hijau $=0: 100)$ & $2,11 \pm 0,91$ & \\
\hline
\end{tabular}
Keterangan : Uji Kruskal-Wallis

Pada Tabel 3, menunjukkan bahwa penilaian tertinggi panelis terhadap karakteristik organoleptik rasa puding silky adalah pada produk P2, kemudian diikuti oleh produk P0, P3 dan P1. Produk puding silky umumnya memiliki rasa yang manis, penambahan kacang hijau yang banyak mengandung glukosa akan meningkatkan rasa manis pada produk puding silky, selain penambahan gula untuk memperbaiki rasa, penambahan susu UHT dan yohgurt juga akan meningkatkan rasa gurih pada produk puding silky. Hasil uji statistik menunjukkan bahwa ada perbedaan atribut rasa pada setiap produk $(p=0,038)$.

\section{Penilaian Organoleptik terhadap Tekstur Puding Silky}

Tekstur merupakan segi penting dari mutu makanan, kadang-kadang lebih penting dari aroma, rasa dan warna. Tekstur suatu produk akan mempengaruhi cita rasa yang ditimbulkan oleh bahan tersebut. Perubahan tekstur suatu bahan dapat mengubah rasa dan bau yang timbul karena dapat mempengaruhi kecepatan timbulnya rangsangan terhadap kelenjar air liur (Winarno, 2004)

Tabel 4. Rerata dan Standar Deviasi Penilaian Organoleptik Tekstur Produk Puding Silky

\begin{tabular}{ccc}
\hline Produk Puding Silky & Rerata & $p$ \\
\hline P0 (Yoghurt : Tepung kacang hijau $=100: 0)$ & $3,02 \pm 0,89$ & \\
PI (Yoghurt : Tepung kacang hijau $=50: 50)$ & $2,46 \pm 0,89$ & 0,001 \\
P2 (Yoghurt : Tepung kacang hijau $=25: 75)$ & $2,57 \pm 0,81$ & \\
P3 (Yoghurt : Tepung kacang hijau $=0: 100)$ & $2,28 \pm 1,01$ & \\
\hline
\end{tabular}
Keterangan : Uji Kruskal-Wallis

Pada Tabel 4, menunjukkan bahwa penilaian tertinggi panelis terhadap karakteristik organoleptik tekstur silky pudding adalah pada produk P0 karena bertekstur sangat lembut dan kenyal. Produk P2 adalah puding silky yang teksturnya paling disukai oleh panelis setelah produk P0. kemudian diikuti oleh produk P1 dan P3. Puding silky P2 memiliki tekstur lembut dan sangat kenyal karena penambahan tepung kacang hijau dan yoghurt. Puding silky Hasil uji statistik menunjukkan bahwa ada perbedaan atribut tekstur pada setiap produk $(p=0,001)$ 
Tekstur kenyal merupakan sifat fisik puding silky dalam daya tahan untuk pecah. Penambahan tepung kacang hijau menambah kekentalan pada puding silky karena kotiledon kacang hijau banyak mengandung pati dan serat (Astawan, 2009). Protein yoghurt menyebabkan puding silky tetap padat dan lemak yoghurt akan membuat puding silky lebih lembut, selain itu susu cair UHT dan yoghurt mengandung penstabil nabati yang akan membentuk kekentalan dan kelembutan tekstur puding silky (Astriliya N, 2019)

Penambahan tepung kacang hijau akan meningkatkan kekerasan dan kekenyalan pada puding silky karena mengandung serat, dapat mengikat air dan mampu membentuk gel (Agustina G, 2007), sedangkan yoghurt merupakan hasil fermentasi dari susu yang merupakan salah satu bahan dasar pada pembuatan puding silky untuk membuat tekstur puding lebih lembut (Nurjanah, Suptijah dan Rani , 2007)

\section{Penilaian Organoleptik Puding Silky Berdasarkan Semua Aspek penilaian}

Pengujian organolpetik disebut juga penilaian dengan indera atau penilaian sensorik dengan panca indera manusia untuk mengamati tekstur, warna, bentuk, aroma dan rasa suatu produk, sehingga diperoleh perlakuan yang terbaik atau yang paling disenangi oleh para panelis (Lailiyana, 2012)

Tabel 5. Penilaian Organoleptik Berdasarkan Semua Aspek penilaian Produk Puding Silky

\begin{tabular}{|c|c|c|c|c|c|c|}
\hline \multirow{2}{*}{ Produk Puding Silky } & \multicolumn{4}{|c|}{ Indikator } & \multirow{2}{*}{ Rerata } & \multirow{2}{*}{$p$} \\
\hline & Warna & Aroma & Rasa & Tekstur & & \\
\hline P0 (Yoghurt : Tepung kacang hijau = $100: 0$ ) & 3,11 & 3,57 & 2,22 & 3,02 & 2,73 & \multirow{4}{*}{0,04} \\
\hline PI (Yoghurt : Tepung kacang hijau = $50: 50)$ & 2,33 & 2,53 & 1,91 & 2,46 & 2,31 & \\
\hline P2 (Yoghurt : Tepung kacang hijau = $25: 75)$ & 2,57 & 2,37 & 2,42 & 2,57 & 2,48 & \\
\hline P3 (Yoghurt : Tepung kacang hijau $=0: 100)$ & 2,4 & 2,15 & 2,11 & 2,28 & 2,24 & \\
\hline
\end{tabular}

Keterangan : Uji Post Hoc

Pada Tabel 5, menunjukkan bahwa daya terima tertinggi oleh panelis berdasarkan semua aspek penilaian (warna, rasa, aroma dan tekstur) terdapat pada produk P0 (kontrol), Produk P2 (Yoghurt : Tepung kacang hijau = 25 : 75) adalah puding silky yang paling disukai oleh panelis setelah produk P0. Puding silky P2 memiliki warna cerah agak kehijauan, rasa manis, tekstur lembut dan kenyal, aroma harum (sesuai bahan penyusun). Hasil uji statistik menunjukkan bahwa ada perbedaan antara produk kontrol dan perlakuan $(p<0,05)$. Oleh karenanya peneliti merekomendasikan puding silky P2 yakni puding silky dengan komposisi 25\% (50 gram) yoghurt dan 75\% (150 gram) tepung kacang hijau dapat dimanfaatkan sebagai makanan tambahan alternatif untuk anak stunting.

\section{Analisis Komposisi Kimia Puding Silky Substitusi Yoghurt dan Tepung Kacang Hijau}

Hasil analsis kimia pada puding silky meliputi kadar protein dan calsium karena tujuan penambahan yoghurt dan tepung kacang hijau adalah untuk meningkatkan kandungan protein dan kalsium puding silky yang 
paling disukai panelis selain produk kontrol. Agar-agar banyak digunakan pada produk berbasis susu karena dapat membentuk kompleks dengan calsium dan protein susu (Winarno, 2004).

Tabel 6. Uji Kimia Puding Silky Substitusi Yoghurt dan Tepung Kacang Hijau per $100 \mathrm{~g}$

\begin{tabular}{|c|c|c|}
\hline Parameter & Satuan & Puding Silky P2 \\
\hline Protein & $g$ & 0,67 \\
\hline Kalsium & $\mathrm{mg}$ & 130 \\
\hline
\end{tabular}

Badan Pengawasan Obat dan Makanan Republik Indonesia (BPOM RI) tahun 2013, menyatakan bahwa dalam $100 \mathrm{~g}$ puding biasa yang sering dikonsumsi anak-anak mengandung kadar calsium 400 mg tetapi tidak mengandung protein. Zat gizi pada puding yang rendah, memerlukan penambahan bahan berupa susu, tepung kacang-kacangan dan telur untuk menjadi puding silky yang bergizi.

Hasil analisis kandungan gizi puding silky P2 diperoleh kadar protein 0,67 g dan kadar kalsium $130 \mathrm{mg}$. Jika kadar protein dan calsium puding silky P2 dibandingkan dengan kadar protein dan kalsium puding standar, menunjukkan bahwa kandungan protein dan kalsium puding silky P2 lebih tinggi bila dibandingkan puding standar.

\section{Analisis Kandungan Protein dan Kalsium Puding Silky P2 Sebagai Alternatif Makanan Tambahan terhadap Prosentase AKG Anak Balita}

Angka Kecukupan Gizi Yang Dianjurkan Bagi Bangsa Indonesia selanjutnya disingkat AKG adalah suatu kecukupan rata-rata zat gizi setiap hari bagi semua orang menurut golongan umur, jenis kelamin, ukuran tubuh, aktifitas tubuh untuk mencapai derajat kesehatan yang optimal.

Tabel 7. Hasil analisis Protein dan Kalsium Produk Puding Silky P2 terhadap Prosentase AKG Anak Balita

\begin{tabular}{lcccc}
\hline \multicolumn{1}{c}{ Parameter } & Satuan & Kadar zat Gizi & AKG & Prosentase AKG \\
\hline Protein & $\mathrm{g}$ & 0,67 & 26 & 2,58 \\
Kalsium & $\mathrm{mg}$ & 130 & 650 & 20 \\
\hline
\end{tabular}

Pada Tabel 7, menunjukkan bahwa protein dan kalsium puding silky P2, sebagai produk yang direkomendasikan sebagai alternatif makanan tambahan pada anak balita yang stunting, menyumbang 2,58\% AKG protein dan 20\% AKG kalsium anak balita. Kandungan gizi makanan tambahan harus mengandung minimal energi 300 kalori dan 5 gram protein atau minimal 15\% dari kebutuhan kalori dan protein setiap harinya (Balitbang Kemendikbud, 2013). Kontribusi makanan tambahan/jajanan terhadap konsumsi sehari berkisar antara 10\%-20\% pada semua kandungan zat gizi pada makanan tambahan (Ulya, 2003). Berdasarkan syarat kandungan 
gizi pada makanan tambahan, puding silky P2 telah memenuhi kadar kalsium makanan tambahan tetapi belum memenuhi kadar protein makanan tambahan, sehingga diharapkan pada pengembangan puding silky selanjutnya perlu ditambahkan bahan makanan yang tinggi protein seperti telur yang biasa digunakan pada pembuatan puding silky.

\section{KESIMPULAN}

Produk P2 (Yoghurt : Tepung kacang hijau = $25: 75$ ) adalah puding silky yang paling disukai oleh panelis setelah produk P0 (kontrol). Puding silky P2 memiliki warna cerah agak kehijauan, rasa manis, tekstur lembut dan kenyal, aroma harum (sesuai bahan penyusun). Hasil analisis kimia produk puding silky P2 mengandung protein 0,67 g dan calsium $130 \mathrm{mg}$, kandungan protein dan calsium puding silky P2 lebih tinggi bila dibandingkan puding standar. Puding silky P2 berkontribusi sebesar 2,58\% terhadap kecukupan gizi protein dan 20\% terhadap kecukupan gizi calsium anak balita. Puding silky P2 layak sebagai makanan tambahan alternatif untuk anak stunting dari segi organoleptik tetapi dari segi gizi puding silky P2 perlu dikaji ulang karena walaupun kadar kalsium puding silky P2 telah memenuhi syarat untuk kadar kalsium makanan tambahan tetapi sangat rendah kadar protein, sehingga diharapkan pada pengembangan puding silky selanjutnya perlu ditambahkan bahan makanan yang tinggi protein seperti telur yang biasa digunakan pada pembuatan puding silky.

\section{DAFTAR PUSTAKA}

Afifah N, 2018. Faktor - Faktor Kejadian Stunting Pada Baduta Di Kabupaten Bombana Pada Tahun 2016 "Analisis Data Hasil Pemantauan Status Gizi Kabupaten Bombana Tahun 2016". Skripsi. Politeknik Kesehatan Kendari

Agustina G, 2007. Aplikasi tepung kacang hijau (Phaseolus radiatus I) dalam pembuatan tepung pudding instan : evaluasi karakteristik fisikokimia dan sensoris. Thesis. Unika Soegijapranata Semarang

Andarwulan N, Kusnandar F, Herawati D. 2011. Analisis Pangan. Dian Rakyat. Jakarta.

Astawan M., 2009. Sehat Dengan Hidangan Kacang dan Biji-Bijian. Penebar Swadaya, Jakarta

Badan Standarisasi Nasional. 2005. SNI 01-2802-2015. Syarat Mutu Puding

Badan POM RI. 2013. Informasi Kandungan Gizi Pangan Jajanan Anak Sekolah.Direktorat Standarisasi Produk Pangan. Badan Pengawas Obat dan Makanan Republik Indonesia. Jakarta 
Depkes RI, 2013. Angka Kecukupan Gizi yang Dianjurkan bagi Bangsa Indonesia. Permenkes RI Nomor 75 Tahun 2013.

Effendi H.M.S. 2009. Teknologi Pengolahan dan Pengawetan Pangan. Penerbit Alfabeta, Bandung.

Hardinsyah dan Supariasa IDN. 2016. IImu Gizi Teori dan Aplikasi. EGC. Jakarta.

Haryono, LV. 2017. Penggunaan Tepung Kacang Hijau pada Pembuatan Flowsuss dan Kahiroll dalam Upaya Pemanfaatan Potensi Lokal. Thesis. Fakultas Teknik, Universitas Yogyakarta. Yogyakarta.

Kemendikbud RI, 2013. Program Kemitraan untuk Pengembangan Kapasitas dan Analisis Pendidikan (ACDP)

Kemenkes RI, 2018. Riset Kesehatan Dasar. Badan Penelitian dan Pengembangan Kesehatan Kementrian Kesehatan RI Tahun 2018.

Lailiyana. 2012. Analisis Kandungan Zat Gizi dan Uji Hedonik Cookies Kaya Gizi Pada Siswi SMPN 27 Pekanbaru Tahun 2012. Thesis. Universitas Indonesia. Depok.

Mitra, 2015. Permasalahan Anak Pendek (Stunting) dan Intervensi Untuk Mencegah Terjadinya Stunting (Suatu Kajian Kepustakaan). Jurnal Kesehatan Komunitas. 2(6): 254-261

Nurhalimah L, Fathonah S, Nuraeni D, 2012. Kandungan Gizi Dan Daya Terima Makanan Tambahan Ibu Hamil Trimester Pertama. Food Science and Culinary Education Journal. 1(1) : 339-340.

Nurjanah, Suptijah P, Rani L. 2007. Pembuatan tepung puding instan karaginan. Buletin Teknologi Hasil Perikanan 1(10): 59-70.

Pricilya, V, 2015. Daya Terima Kacang Hijau (Phaseolus Radiata L) dan Bekatul (Rice Bran) terhadap Kandungan Serat pada Snack Bar. Fakultas Kesehatan Masyarakat, Universitas Airlangga. Media Gizi Indonesia, $10(2): 136-140$.

Sari EM, Juffrie M, Nurani N dan Sitaresmi MN. 2016. Asupan Protein, Kalsium dan Fosfor pada Anak Stunting dan tidak Stunting pada usia 24 - 59 bulan. Jurnal Gizi Klinik Indonesia. 12(4) : 152 - 159)

Supariasa IDN, Bakri B, Fajar I. 2016. Penilaian Status Gizi. Penerbit Buku Kedokteran EGC. Jakarta.

Winarno FG. 2004. Kimia Pangan dan Gizi. Penerbit Gramedia Pustaka Utama. Jakarta

Yasjudani A. 2017. Uji Organoleptik Pembuatan Silky Pudding Dengan Penambahan Yoghurt Dan Buah Naga Merah (Hylocereus Costaricensis). Skripsi. Jurusan Tata Boga. Politeknik Negeri Balikpapan. Balikpapan. 